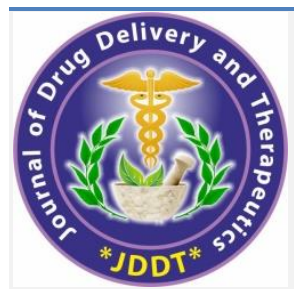

()

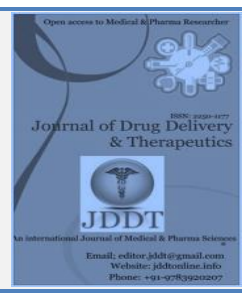

\title{
A Review on Some Medicinal Plants of North- East India Region Used in the Treatment of Central Nervous System Disorders
}

\author{
Venessa Nath (1D*, Parishmita Buragohain, Hemanta Kr. Sharma ${ }^{(D)}$ \\ Department of Pharmaceutical Sciences, Dibrugarh University, Dibrugarh, Assam, 786004, India
}

Article Info:

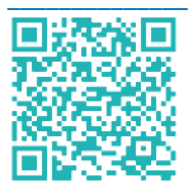

\section{Article History:}

Received 04 July 2021

Reviewed 28 August 2021

Accepted 04 Sep 2021

Published 15 Sep 2021

\section{Cite this article as:}

Nath V, Buragohain P, Sharma HK, A Review on Some Medicinal Plants of North- East India Region Used in the Treatment of Central Nervous System Disorders, Journal of Drug Delivery and

Therapeutics. 2021; 11(5):199-207

DOI: http://dx.doi.org/10.22270/jddt.v11i5.5033

\section{*Address for Correspondence:}

Venessa Nath, Department of Pharmaceutical Sciences, Dibrugarh University, Dibrugarh, Assam, 786004 , India

ORCID ID: https://orcid.org/0000-0001-5721-0744

\section{Abstract}

Background: Central nervous system (CNS) disorders are a group of neurological disorders concerned with behaviour, coordination and functioning of the brain and the spinal cord. The CNS is the site of processing various informations. It interprets and evaluates the information and as result, the CNS responds accordingly and controls the body. Any defects or disorders of the Central nervous system may cause degeneration of the organs and tissues associated with it, loss of coordination, paralysis, etc. These disorders may be hereditary or due to injuries to the brain and spinal cord. Although, these disorders are being cured with medicaments, many plant species are also seen to be effective in its treatment. Objective: the main objective of this article is to underline the potentials and the needs for the documentation of the ecological knowledge of herbal medicines of the north east India region, necessary for the greater well-being of mankind in the prevention and cure of CNS disorders. Methods: an extensive literature survey was carried out through various databases like Google Scholar, Pubmed, Sciencedirect etc to support this review. All the collected information was analyzed accordingly and the plants were enlisted based on the classes of CNS disorders for which they are used. Result and discussion: from the survey of the database being collected, it was found that many traditional and local plants of the northeast India region are therapeutically effective in the treatment and cure of many Central nervous system disorders. Conclusion: It is now an accepted fact that many traditional plants found in the Northeast India have been acceptable within the human body and hence these can be used to replace many expensive medications available in the market.

Keywords: Medicinal plants; Central Nervous System; CNS disorders; Northeast India; Plant extract

\section{INTRODUCTION}

The Central Nervous System (CNS) is one of the major divisions of the Nervous System consisting of the brain and the spinal cord. When examined by physiologists and anatomists, it was found to be playing a very major role in our body's function. It co-relates information from different parts of the body and coordinates activities across the entire human framework. The CNS controls many functions in our body. For example it controls our thoughts, emotions, body movements, behaviour, mood, appetite, desires, body temperature, release of hormones and much more. ${ }^{1}$

Central nervous system (CNS) disorder is a general class of conditions where the brain does not function or work as it should have, restricting the wellbeing and the capacity to work. The condition might be an acquired metabolic issue; the latter effect of harm from a disease, a degenerative condition, stroke, a brain tumour or other issues; or emerge from obscure or multiple factors. Movement disorders, for example, Parkinson's disease, dystonia and other basic tremor are conditions reflected by the CNS. What they share practically speaking is the loss of adequate, intact nervous system circuits that arrange capacities as fluctuated as memory development (in Alzheimer's) or voluntary movement (in movement disorders). While most conditions in this gathering cannot be totally restored, symptoms of central nervous system illness can often be managed through a range of therapies, from clinical to surgical treatment. Although, not many medications are as of now endorsed by administrative experts for treating these disorders, for example, Alzheimer's disease.

Use of plants for curing ailments is an ancient old practice. Even today, most of the population still depends on the traditional medicine therapy for primary well being .CNS disorders that are seen by an impact on activities essentially associated with the CNS are thought of. CNS functions such as cognition, alertness, memory sedation, etc can be considered as targets for treatment with plants and their constituents. As the activity of a plant or its extract depends generally on its chemical constituents, the majority of plants affect the CNS by providing compounds that act in the same, or opposite, way as the chemical transmitters found in the brain, which accelerates or inhibits the chemical transformations in the CNS. Hence, the herbal treatment ensures the CNS directly or indirectly against harmful chemicals or processes 2 . The Indian traditional system of medicine, Ayurveda, which is over 5000 years old, chosen plants have for some time been named 'medhyarasayanas', 
from the Sanskrit words 'medhya', which means intellect or cognition and 'rasayana', signifying 'revival'. 3-6

However, an aim to audit some of the most significant restorative plants found in the northeast region of India, including Ginkgo biloba, Bacopamonniera, Hydrocotyle asiatica, etc., which are generally utilized for their presumed adequacy in CNS disorders are seen here.

\section{MATERIALS AND METHODS}

In order to collect the data provided which support this review article, we performed an extensive literature survey of abstracts from 1999-2020. A systematic review using
Sciencedirect, Scopus, Pubmed, Google and MEDLINE database is performed.

All English-language articles published between 1999-2019 were searched using the terms 'Medicinal plants', ' Northeast region plants', 'CNS Disorders', 'Plant extract', 'traditional uses of medicinal plants'. Evidence for the support of an extract was assessed from multiple studies. In this article, we have summarized and offered comments about the selected area and also identified some relevant changes and included some additional information that will assist and better understanding of the current state of medicinal care offered by some important plant species.

TABLE: Medicinal plants of North- East India region used for the treatment of CNS disorder

CATEGORY A: Medicinal plants used for the treatment of Epilepsy

\begin{tabular}{|c|c|c|c|c|}
\hline S. No. & Name of the plant & $\begin{array}{l}\text { Parts of the } \\
\text { plant used }\end{array}$ & Forms and Preparation & Ref \\
\hline 1. & $\begin{array}{l}\text { Acorus calamus } \mathrm{L} ., \\
\text { (Acoraceae) }\end{array}$ & $\begin{array}{l}\text { Roots and } \\
\text { leaves }\end{array}$ & Roots and leaf decoction is used for the treatment & [7] \\
\hline 2. & $\begin{array}{l}\text { Annona squamosaL., } \\
\text { (Annonaceae) }\end{array}$ & Seeds & The smoke of burning seeds is inhaled for the treatment & [8] \\
\hline 3. & $\begin{array}{l}\text { Benincasa hispida } \\
\text { (Cucurbitaceae) }\end{array}$ & Fruits & It is also given orally in epilepsy and other nervous disorders. & [8] \\
\hline 4. & $\begin{array}{l}\text { Eryngium foetidum L. } \\
\text { (Apiaceae), }\end{array}$ & Leaves & It is given to patient of epilepsy to smell the leaf paste & [7] \\
\hline 5. & $\begin{array}{l}\text { Sapindus mukorossiGaertn. } \\
\text { (Sapindaceae); }\end{array}$ & Fruits & $\begin{array}{l}\text { Fruits are crushed to paste and mixed thoroughly with water } \\
(30 \mathrm{ml}) . \text { It is taken orally }(20 \mathrm{ml} \text { daily, before food }) \text { in the } \\
\text { treatment. }\end{array}$ & [9] \\
\hline 6. & $\begin{array}{l}\text { Taxus baccataLinn. } \\
\text { (Taxaceae) }\end{array}$ & Leaves & Leaf extract are used in the treatment of epilepsy. & [9] \\
\hline 7. & $\begin{array}{l}\text { Vitex negundoLinn. } \\
\text { (lamiaceae); }\end{array}$ & Root bark & $\begin{array}{l}\text { Root bark is ground and mixed with local liquor to make a } \\
\text { paste. The paste is applied over neck in the treatment. }\end{array}$ & [9] \\
\hline
\end{tabular}

CATEGORY B: Medicinal plants used for the treatment of Convulsions/Seizures

\begin{tabular}{|c|c|c|c|c|}
\hline $\begin{array}{l}\text { S. } \\
\text { No. }\end{array}$ & Name of the plant & $\begin{array}{l}\text { Parts of the } \\
\text { plant used }\end{array}$ & Forms and Preparation & Ref \\
\hline 1. & AnanascomosusMerr.(Bromeliaceae) & $\begin{array}{l}\text { Fruits and } \\
\text { Leaves }\end{array}$ & $\begin{array}{l}\text { The juice of the fruit and of leaves is given orally in the } \\
\text { treatment of convulsions. }\end{array}$ & [8] \\
\hline 2. & Eryngium foetidum L.(Apiaceae) & Leaves & $\begin{array}{l}\text { It is also used orally to stop convulsions during high } \\
\text { fever. }\end{array}$ & [8] \\
\hline 3. & Helicia excelsa Bl. (Proteaceae) & Seeds & $\begin{array}{l}\text { A necklace is prepared with seeds and worn around } \\
\text { the neck as an effective remedy in convulsions. }\end{array}$ & [8] \\
\hline 4. & $\begin{array}{l}\text { Ensete superbum } \\
\text { (Musaceae) }\end{array}$ & Arial part & $\begin{array}{l}\text { The exudates }(2-5 \mathrm{ml}) \text { is given orally ( } 2-3 \text { times daily) } \\
\text { in the treatment of convulsion. The latex of the } \\
\text { inflorescence is taken orally in convulsions. }\end{array}$ & [8] \\
\hline 5. & $\begin{array}{l}\text { Artemisia vulgaris } \\
\text { (Asteraceae) }\end{array}$ & Leaves & $\begin{array}{l}\text { A soft moist mass leaves kept in place with a cloth and } \\
\text { applied to reduce inflammation }\end{array}$ & [20] \\
\hline 6. & $\begin{array}{l}\text { Matricaria chamomillaL. } \\
\text { (Asteraceae) }\end{array}$ & Plant extract & $\begin{array}{l}220-1110 \mathrm{mg} \text { of the plant extract daily for } 8 \text { weeks } \\
\text { can be beneficial. }\end{array}$ & [24] \\
\hline
\end{tabular}


CATEGORY C: Medicinal plants used for the treatment of Alzheimer disease

\begin{tabular}{|c|c|c|c|c|}
\hline S. No. & Name of the plant & $\begin{array}{l}\text { Parts of the } \\
\text { plant used }\end{array}$ & Forms and Preparation & Ref \\
\hline 1. & Curcuma longaL. (Zingiberaceae) & Root & $\begin{array}{l}\text { A small dose of the root extract is given and then } \\
\text { eventually increasing t to } 500-2000 \mathrm{mg} \text { per day } \\
\text { mixed with black pepper extract. }\end{array}$ & $\begin{array}{l}{[10]} \\
{[13]}\end{array}$ \\
\hline 2. & $\begin{array}{l}\text { Bacopa monnieri (L.) Wettst. } \\
\text { (Scrophulariaceae) }\end{array}$ & $\begin{array}{l}\text { Leaves and } \\
\text { Stems }\end{array}$ & T he extract is taken orally for upto 12 weeks. & $\begin{array}{l}\text { [15], [18], } \\
{[19]}\end{array}$ \\
\hline 3. & $\begin{array}{l}\text { Hydrocotyle asiatica } \\
\text { (Apiaceae) }\end{array}$ & Extract & $60-180 \mathrm{mg}$ of golu kola extract daily to be used. & $\begin{array}{l}{[21],[22],} \\
{[23]}\end{array}$ \\
\hline 4. & Gingko biloba (Ginkgoaceae) & Leaves & $\begin{array}{l}120-600 \mathrm{mg} \text { of leaf extract is taken orally two } \\
\text { times daily. }\end{array}$ & {$[25]$} \\
\hline 5. & $\begin{array}{l}\text { Camellia sinensis (L.) Kuntze } \\
\text { (Theacae) }\end{array}$ & Extract & $\begin{array}{l}\text { the extract from the plant part can be used to } \\
\text { make tea with water by the process of ebullition. } \\
1-3 \text { cups or } 60 \mathrm{mg} \text { on regular basis is used. }\end{array}$ & {$[26]$} \\
\hline 6. & $\begin{array}{l}\text { Celastrus paniculatus Willd. } \\
\text { (Celastraceae) }\end{array}$ & Seeds & $\begin{array}{l}\text { Oil is extracted from the seeds and the sedative } \\
\text { effect. }\end{array}$ & {$[30]$} \\
\hline 7. & Allium sativum (Amaryllidaceae) & Bulb & $\begin{array}{l}\text { Eating raw garlic on empty stomach helps to } \\
\text { counteract age-related- changes in gut bacteria } \\
\text { associated with the memory loss }\end{array}$ & $\begin{array}{l}{[41],[42],} \\
{[43],[44]}\end{array}$ \\
\hline 8. & $\begin{array}{l}\text { Phyllanthus emblica } \mathbf{L} \text {. } \\
\text { (phyllanthaceae) }\end{array}$ & Extract & $\begin{array}{l}\text { The extract of the fruit are given to the } \\
\text { Alzheimer patient }\end{array}$ & {$[38]$} \\
\hline 9. & $\begin{array}{l}\text { Crocus sativus } \mathbf{L} . \\
\text { (Iridaceae) }\end{array}$ & $\begin{array}{l}\text { The dried } \\
\text { stigmas }\end{array}$ & $\begin{array}{l}30 \mathrm{mg} \text { of the dried stigma extract is used daily for } \\
22 \text { weeks }\end{array}$ & [33] \\
\hline
\end{tabular}

CATEGORY D: Medicinal plants used for the treatment of depression

\begin{tabular}{|c|c|c|c|c|}
\hline S. No. & Name of the plant & $\begin{array}{l}\text { Parts of the plant } \\
\text { used }\end{array}$ & Forms and Preparation & Ref \\
\hline 1. & $\begin{array}{l}\text { Valeriana officinalis } \mathbf{L} . \\
\text { (Caprifoliaceae) }\end{array}$ & Extract & $60-180 \mathrm{mg}$ of golu kola extract daily to be used. & {$[20]$} \\
\hline 2. & $\begin{array}{l}\text { Bacopa monnieri (L.) } \\
\text { Wettst. } \\
\text { (Scrophulariaceae) }\end{array}$ & Leaves and Stems & the extract is taken orally for upto 12 weeks. & [17] \\
\hline 3. & $\begin{array}{l}\text { Ocimum tenuiflorum } \\
\text { (Lamiaceae) }\end{array}$ & Leaves & $\begin{array}{l}\text { 10-12 leaves are added in } 2 \text { cups of water and then } \\
\text { ebullition takes place and it is reduced till half a cup. } \\
\text { It is allowed to cool at room temperature and then } \\
\text { strained and } 1 \text { teaspoon of honey is added to it. }\end{array}$ & {$[34]$} \\
\hline 4. & $\begin{array}{l}\text { Crocus sativus L. } \\
\text { (Iridaceae) }\end{array}$ & The dried stigmas & $\begin{array}{l}30 \mathrm{mg} \text { of saffron extract or } 100 \mathrm{mg} \text { of saffron daily } \\
\text { upto } 12 \text { weeks. }\end{array}$ & [33] \\
\hline 5. & $\begin{array}{l}\text { Curcuma longaL. } \\
\text { (Zingiberaceae) }\end{array}$ & Stem & $\begin{array}{l}500 \mathrm{mg} \text { of curcumin , a chemical in turmeric, has been } \\
\text { taken twice daily, alone or along with } 20 \mathrm{mg} \text { of } \\
\text { fluoxetine daily, for } 6-8 \text { weeks. }\end{array}$ & $\begin{array}{l}\text { [11], [12], } \\
{[13]}\end{array}$ \\
\hline 6. & $\begin{array}{l}\text { Marsilea minuta } \\
\text { (Marsileaceae) }\end{array}$ & Leaves & $\begin{array}{l}\text { Fresh leaf decoction is taken twice a day for } 10-12 \\
\text { days. }\end{array}$ & [39] \\
\hline
\end{tabular}


CATEGORY E: Medicinal plants used for the treatment of anxiety

\begin{tabular}{|c|c|c|c|c|}
\hline S. No. & Name of the plant & $\begin{array}{l}\text { Parts of the } \\
\text { plant used }\end{array}$ & Forms and Preparation & Ref \\
\hline 1. & $\begin{array}{l}\text { Mentha } \times \text { piperita } \\
\text { (Lamiaceae) }\end{array}$ & Oil and extract & $\begin{array}{l}\text { The patients are given aromatherapy with peppermint } \\
\text { essence and distilled water. Upto } 1200 \mathrm{mg} \text { of } \\
\text { peppermint oil ia also found beneficial. }\end{array}$ & {$[40]$} \\
\hline 2. & $\begin{array}{l}\text { Aloe barbadensis Mill. } \\
\text { (Asphodelaceae) }\end{array}$ & Extract & The extract is consumed directly for betterment. & {$[27]$} \\
\hline 3. & $\begin{array}{l}\text { Coriandrum sativumL. } \\
\text { (Apiaceae) }\end{array}$ & Leaf & $\begin{array}{l}\text { The extract from the plant part of } 100-200 \mathrm{mg} / \mathrm{kg} \\
\text { produces anti anxiety effects on the patients. }\end{array}$ & $\begin{array}{l}35] \\
{[36]}\end{array}$ \\
\hline 4. & $\begin{array}{l}\text { Valeriana officinalis L. } \\
\text { (Caprifoliaceae) }\end{array}$ & Extract & $60-180 \mathrm{mg}$ of golu kola extract daily to be used. & {$[20]$} \\
\hline 5. & $\begin{array}{l}\text { Passiflora } \\
\text { Incarnate } \\
\text { (Passifloraceae) }\end{array}$ & Arial part & $\begin{array}{l}\text { Capsules containing } 400 \mathrm{mg} \text { of passionflower extract } \\
\text { twice daily for } 2-8 \text { weeks can be used. Also, } 45 \text { drops of } \\
\text { a liquid extract of passion flower has been used daily for } \\
\text { upto one month. }\end{array}$ & [48] \\
\hline 6. & $\begin{array}{l}\text { Crocus sativus L. } \\
\text { (Iridaceae) }\end{array}$ & The dried stigmas & $\begin{array}{l}30 \mathrm{mg} \text { of saffron extract or } 100 \mathrm{mg} \text { of saffron daily upto } \\
12 \text { weeks. }\end{array}$ & [33] \\
\hline 7. & $\begin{array}{l}\text { Bacopamonnieri (L.) } \\
\text { Wettst. } \\
\text { (Scrophulariaceae) }\end{array}$ & Leaves and Stems & The extract is taken orally for upto 12 weeks. & $\begin{array}{l}{[15],[16],} \\
{[17]}\end{array}$ \\
\hline 8. & $\begin{array}{l}\text { Withania } \\
\text { Somnifera(L.) Dunal } \\
\text { (Solanaceae) }\end{array}$ & Roots & 500- $600 \mathrm{mg}$ per day for 6-12 weeks & [37] \\
\hline
\end{tabular}

CATEGORY F: Medicinal plants used for the treatment of paralytic disorders

\begin{tabular}{|c|c|c|c|c|}
\hline S. No. & Name of the plant & $\begin{array}{l}\text { Parts of the } \\
\text { plant used }\end{array}$ & Forms and Preparation & Ref \\
\hline 1. & $\begin{array}{l}\text { Acorus calamus L., } \\
\text { (Araceae) }\end{array}$ & $\begin{array}{l}\text { Roots and } \\
\text { Leaves }\end{array}$ & $\begin{array}{l}\text { Leaf decoction is taken daily in case of paralysis. } \\
\text { Decoction of underground plant part is fomented on the } \\
\text { body of a paralytic patient. }\end{array}$ & $\begin{array}{l}{[31]} \\
{[32]}\end{array}$ \\
\hline 2. & $\begin{array}{l}\text { Gaultheria } \\
\text { fragrantissima Wall. } \\
\text { (Ericaceae) }\end{array}$ & Leaves & $\begin{array}{l}\text { Leaf juice of Gaultheria fragrantissima Wall, Clerodendron } \\
\text { colebrookianum Walp. and Eucalyptus maculata Hook. is } \\
\text { massaged over the body of persons suffering from } \\
\text { paralysis }\end{array}$ & [49] \\
\hline 3. & $\begin{array}{l}\text { Phrynium pubinerve } \\
\text { Blume., (Marantaceae) }\end{array}$ & Rhizome & $\begin{array}{l}\text { Plant rhizome along with mature leaves of Zanthoxylum } \\
\text { acanthopodium DC., Pteridium aquilinum rhizome, } \\
\text { Sarcandra glabra (Thunb.) Nakai. Leaves and. Phrynium } \\
\text { pubinerve Blume. leaves are mixed together and ground. } \\
\text { The fine mixture is then wrapped into many small packets } \\
\text { with Phrynium pubinerve Bl. leaf and the packets are } \\
\text { heated in the fire covered with ash so that they do not get } \\
\text { burnt. After half an hour all the packets are taken out while } \\
\text { it is hot and the contents of each packet is emptied into a } \\
\text { piece of white cloth and tied at one end. It is then fomented } \\
\text { on the body of persons suffering from paralytic conditions. }\end{array}$ & [49] \\
\hline 4. & $\begin{array}{l}\text { Piper longum } L \text {. } \\
\text { (Piperaceae) }\end{array}$ & Roots & $\begin{array}{l}\text { The root decoction ( } 5-20 \mathrm{ml}, 2-5 \text { times daily) is taken orally } \\
\text { in the treatment of paralytic conditions. }\end{array}$ & [49] \\
\hline 5. & $\begin{array}{l}\text { Persicaria nepalensis } \\
\text { (Polygonaceae) }\end{array}$ & Rhizome & $\begin{array}{l}\text { Plant rhizome along with mature leaves of Zanthoxylum } \\
\text { acanthopodium DC., Pteridium aquilinum rhizome, } \\
\text { Sarcandra glabra (Thunb.) Nakai. Leaves and persicaria } \\
\text { nepalensis. Leaves are mixed together and ground. The fine } \\
\text { mixture is then wrapped into many small Herbal remedies } \\
\text { among the traditional folks in Meghalaya. Packets with } \\
\text { Phrynium pubinerve Bl. leaf and the packets are heated in } \\
\text { the fire covered with ash so that they do not get burnt. After }\end{array}$ & [49] \\
\hline
\end{tabular}




\begin{tabular}{|c|c|c|c|c|}
\hline & & & $\begin{array}{l}\text { half an hour all the packets are taken out while it is hot and } \\
\text { the contents of each packet is emptied into a piece of white } \\
\text { cloth and tied at one end. It is then fomented on the body of } \\
\text { persons suffering from paralytic conditions. }\end{array}$ & \\
\hline 6. & $\begin{array}{l}\text { Polygonatum } \\
\text { oppositifolium Royle., } \\
\text { (Liliaceae) }\end{array}$ & Rhizome & $\begin{array}{l}\text { Plant rhizome along with mature leaves of Zanthoxylum } \\
\text { acanthopodium DC., Pteridium aquilinum rhizome, } \\
\text { Sarcandra glabra (Thunb.) Nakai. leaves and Phrynium } \\
\text { pubinerve Blume. leaves are mixed together and ground. } \\
\text { The fine mixture is then wrapped into many small packets } \\
\text { with Phrynium pubinerve Bl. leaf and the packets are } \\
\text { heated in the fire covered with ash so that they do not get } \\
\text { burnt. After half an hour all the packets are taken out while } \\
\text { it is hot and the contents of each packet is emptied into a } \\
\text { piece of white cloth and tied at one end. It is then fomented } \\
\text { on the body of persons suffering from paralytic conditions. }\end{array}$ & [49] \\
\hline 7. & $\begin{array}{l}\text { Pteridium aquilinum } \\
\text { (L.) Kuhn ex Decken } \\
\text { (Polypodiaceae) }\end{array}$ & Rhizome & $\begin{array}{l}\text { Plant rhizome alongwith mature leaves of Zanthoxylum } \\
\text { acanthopodium DC., Pteridium aquilinum rhizome, } \\
\text { Sarcandra glabra (Thunb.) Nakai. leaves and Polygonum } \\
\text { alatum Spreng. leaves are mixed together and ground. The } \\
\text { fine mixture is then wrapped into many small packets with } \\
\text { Phrynium pubinerve Bl. leaf and the packets are heated in } \\
\text { the fire covered with ash so that they do not get burnt. After } \\
\text { half an hour all the packets are taken out while it is hot and } \\
\text { the contents of each packet is emptied into a piece of white } \\
\text { cloth and tied at one end. It is then fomented on the body of } \\
\text { persons suffering from paralytic conditions. }\end{array}$ & [49] \\
\hline 8. & $\begin{array}{l}\text { Zanthoxylum } \\
\text { acanthopodium DC. } \\
\text { (Rutaceae) }\end{array}$ & Rhizome & $\begin{array}{l}\text { Plant rhizome alongwith mature leaves of Zanthoxylum } \\
\text { acanthopodium DC., Pteridium aquilinum rhizome, } \\
\text { Sarcandra glabra (Thunb.) Nakai. leaves and Polygonum } \\
\text { alatum Spreng. leaves are mixed together and ground. The } \\
\text { fine mixture is then wrapped into many small packets with } \\
\text { Phrynium pubinerve Bl. leaf and the packets are heated in } \\
\text { the fire covered with ash so that they d onot get burnt. After } \\
\text { half an hour all the packets are taken out while it is hot and } \\
\text { the contents of each packet is emptied into a piece of white } \\
\text { cloth and tied at one end. It is then fomented on the body of } \\
\text { persons suffering from paralytic conditions. }\end{array}$ & [49] \\
\hline
\end{tabular}

\section{G: Medicinal plants used for the treatment of Parkinson's disease}

\begin{tabular}{|c|c|c|c|c|}
\hline S. No. & Name of the plant & $\begin{array}{l}\text { Parts of the plant } \\
\text { used }\end{array}$ & Forms and Preparation & Ref \\
\hline 1. & $\begin{array}{l}\text { Mucuna prurienes } \\
\text { (Fabacea) }\end{array}$ & Seeds & $\begin{array}{l}5 \mathrm{~g} \text { of Mucuna prurienes dried seed powder has been } \\
\text { used on daily basis. }\end{array}$ & {$[50]$} \\
\hline 2. & $\begin{array}{l}\text { Curcuma longaL. } \\
\text { (Zingiberaceae) }\end{array}$ & Stem & $\begin{array}{l}\text { Starting with a lower dose of the extract and then } \\
\text { eventually increasing t to } 500-2000 \mathrm{mg} \text { per day } \\
\text { mixed with black pepper extract. }\end{array}$ & {$[10],[13]$} \\
\hline 3. & $\begin{array}{l}\text { Withania somnifera } \\
\text { (Solanaceae) }\end{array}$ & Roots & $125 \mathrm{mg}-5 \mathrm{~g}$ for $1-3$ months have been beneficial & [37] \\
\hline 4. & $\begin{array}{l}\text { Bacopa monnieri(L.) } \\
\text { Wettst } \\
\text { (Scrophulariaceae) }\end{array}$ & Leaves and Stems & the extract is taken orally for upto 12 weeks. & {$[[15]$} \\
\hline 5. & $\begin{array}{l}\text { Camellia sinensis }(\mathrm{L} .) \\
\text { Kuntze } \\
\text { (Theacae) }\end{array}$ & Extract & $\begin{array}{l}\text { the extract from the plant part can be used to make } \\
\text { tea with water by the process of ebullition. } 1-3 \text { cups } \\
\text { or } 60 \mathrm{mg} \text { on regular basis is used. }\end{array}$ & {$[26]$} \\
\hline 6. & $\begin{array}{l}\text { Hydrocotyle asiatica } \\
\text { (Apiaceae) }\end{array}$ & Extract & $60-180 \mathrm{mg}$ of golu kola extract daily to be used. & $\begin{array}{l}{[21],[22],} \\
{[23]}\end{array}$ \\
\hline
\end{tabular}


CATEGORY H: Medicinal plants used for the treatment of Attention Deficit Hyperactivity Disorder (ADHD)

\begin{tabular}{|c|c|c|c|c|}
\hline $\begin{array}{l}\text { S. } \\
\text { No. }\end{array}$ & Name of the plant & $\begin{array}{l}\text { Parts of the } \\
\text { plant used }\end{array}$ & Forms and Preparation & Ref \\
\hline 1. & $\begin{array}{l}\text { Gingko biloba } \\
\text { (Ginkgoaceae) }\end{array}$ & Leaves & $120-600 \mathrm{mg}$ of leaf extract is taken orally two times daily. & [25] \\
\hline 2. & $\begin{array}{l}\text { Bacopamonniera } \\
\text { (Scrophulariaceae) }\end{array}$ & $\begin{array}{l}\text { Leaves and } \\
\text { Stems }\end{array}$ & The extract is taken orally for upto 12 weeks. & $\begin{array}{l}{[15],[16],} \\
{[17]}\end{array}$ \\
\hline 3. & Panaxgingseng(Araliaceae) & Roots & $0.5-2 \mathrm{~g}$ of the dried root per day on short term basis. & [45] \\
\hline 4. & Pinusmaritima(Pinaceae) & Extract & $\begin{array}{l}\text { The extract from the bark called pycnogenol is given to } \\
\text { children with ADHD in a dose of } 1 \mathrm{mg} \text { for four weeks. Also, } \\
\text { in adults with ADHD, it decreases the dopamine by nearly } \\
11 \% \text {. }\end{array}$ & [51] \\
\hline 5. & $\begin{array}{l}\text { Centellaasiatica } \\
\text { (Umbelliferae) }\end{array}$ & Extract & $60-180 \mathrm{mg}$ of golu kola extract daily to be used. & $\begin{array}{l}{[21],[22],} \\
{[23]}\end{array}$ \\
\hline
\end{tabular}

CATEGORY I: Medicinal plants used for the treatment of bacterial meningitis

\begin{tabular}{|c|l|l|l|l|}
\hline S. No. & Name of the plant & $\begin{array}{l}\text { Parts of the } \\
\text { plant used }\end{array}$ & Forms and Preparation & Ref \\
\hline $\mathbf{1 .}$ & $\begin{array}{l}\text { Allium sativum } \\
\text { (Amaryllidaceae) }\end{array}$ & Bulb & $\begin{array}{l}\text { Allicin , its active ingredient and alternative organic } \\
\text { compounds in garlic area unit loaded with anti oxidant have } \\
\text { antiviral capabilities that help in elimination and interference } \\
\text { of infections. }\end{array}$ & $\begin{array}{l}{[41],} \\
{[42],} \\
{[43],[44]}\end{array}$ \\
\hline $\mathbf{2 .}$ & $\begin{array}{l}\text { Ganoderma lucidum } \\
\text { (Curtis) P.Karst. } \\
\text { (polyporaceae) }\end{array}$ & Stem & $\begin{array}{l}\text { 6-12g of ganodermalucidum extract daily for around 12 } \\
\text { weeks is found to be beneficial }\end{array}$ & {$[47]$} \\
\hline $\mathbf{3 .}$ & $\begin{array}{l}\text { Olea europaeaL. } \\
\text { (Oleaceae) }\end{array}$ & Leaves & $\begin{array}{l}\text { The leaves are dried or are prepared in capsule forms to be } \\
\text { utilized for treatment. }\end{array}$ & {$[46]$} \\
\hline $\mathbf{4 .}$ & $\begin{array}{l}\text { Panax gingseng } \\
\text { (Araliaceae) }\end{array}$ & Roots & $\begin{array}{l}\text { It is consumed directly or stewed during a tea to get pleasure } \\
\text { from the advantages of the ancient remedy. }\end{array}$ & {$[45]$} \\
\hline $\mathbf{5 .}$ & $\begin{array}{l}\text { Nepeta cataria } \\
\text { (Laminaceae) }\end{array}$ & Leaves & $\begin{array}{l}\text { The herb is stewed in water and also the liquor created is } \\
\text { drunk like tea. }\end{array}$ & {$[28],[29]$} \\
\hline $\mathbf{6 .}$ & $\begin{array}{l}\text { Aloe barbadensis Mill. } \\
\text { (Asphodelaceae) }\end{array}$ & Extract & The extract is consumed directly for betterment. & {$[27]$} \\
\hline
\end{tabular}

CATEGORY J: Medicinal plants used for the treatment of multiple sclerosis

\begin{tabular}{|c|c|c|c|c|}
\hline S. No. & Name of the plant & $\begin{array}{l}\text { Parts of the } \\
\text { plant used }\end{array}$ & Forms and Preparation & Ref \\
\hline 1. & $\begin{array}{l}\text { Zingiber } \\
\text { officinale(Zingiberaceae) }\end{array}$ & $\begin{array}{l}\text { Ginger } \\
\text { extract }\end{array}$ & $200-300 \mathrm{mg} / \mathrm{kg}$ ginger extract is taken on daily basis & [52] \\
\hline 2. & $\begin{array}{l}\text { Curcuma longa } \mathrm{L} . \\
\text { (Zingiberaceae) }\end{array}$ & $\begin{array}{l}\text { Curcumin } \\
\text { extract }\end{array}$ & $\begin{array}{l}50-2000 \mathrm{mg} \text { /day decreases CNS inflammation and } \\
\text { demyelisation also, decreases the severity of EAE. }\end{array}$ & [13], [14] \\
\hline 3. & $\begin{array}{l}\text { Camellia sinensisL. } \\
\text { (Theaceae) }\end{array}$ & Extract & $\begin{array}{l}\text { Treatment with } 600 \mathrm{mg} / \text { day with epigallocatechin-3-gallate } \\
\text { (EGCE) improves muscle metabolism during moderate } \\
\text { exercise in MS patients. }\end{array}$ & [52] \\
\hline 4. & $\begin{array}{l}\text { Valeriana officinalisL. } \\
\text { (Caprifoliaceae) }\end{array}$ & Extract & $60-180 \mathrm{mg}$ of golu kola extract daily to be used. & [52] \\
\hline 5. & $\begin{array}{l}\text { Nigella sativaL. } \\
\text { (Ranunculaceae) }\end{array}$ & Seeds and oil & $\begin{array}{l}\text { the extract from the plant part is used suppressed } \\
\text { inflammation and demyelisation in the CNS }\end{array}$ & {$[52]$} \\
\hline 6. & $\begin{array}{l}\text { Panax ginseng C.A.Mey. } \\
\text { (Araliaceae) }\end{array}$ & roots & $\begin{array}{l}\text { Gingseng roots are used in powdered form the infiltration } \\
\text { of inflammatory cells in the CNS. Also it has no adverse } \\
\text { effect on MS patients as well as reduces fatigue and has a } \\
\text { positive effect on quality of life. }\end{array}$ & [45] \\
\hline 7. & $\begin{array}{l}\text { Gingko biloba } \\
\text { (Ginkgoaceae) }\end{array}$ & Leaves & $\begin{array}{l}240 \mathrm{mg} / \text { day of the leaf extract relieves fatigue with no } \\
\text { adverse effect on MS patients. }\end{array}$ & [25] \\
\hline
\end{tabular}




\section{RESULT AND DISCUSSION}

In the present scenario, many traditional species of plants from the North East region of India are reported to have been effective in the treatment of neurological disorders with most of them belonging to the families of Apiaceae, Ginkgoaceae, Theaceae, etc . These species are widely distributed among the seven states of north-east and over the years have been preserved by the locals folks of the region. Mental and neurological disorders has always been a major health issue among the individuals and the use of medicinal plants for its treatment marks as a milestone as it would be cost efficient and with least side effects. Also, these medicinal plants are found to have great antioxidant property mainly due to the presence of phytochemical constituents. So, the use of these plants can therefore provide enormous public health benefits, particularly in the third world country. However, after decades of research, documentation and examination of the medicinal properties of the plants, this sector still lacks behind. This is because most of the investigations are done at preliminary levels without proper scientific base and mankind do not have access to proper knowledge about the benefits these plants provide to us. Treatment with medicinal plants has a holistic approach. It has to be is integrated emotionally, physically, mentally and spiritually in our lives. Therefore, in the coming years, it will provide greater scope in health sector of living being.

\section{CONCLUSION}

It is now an accepted fact that many traditional plants found in Northeast India have better compatibility and acceptability within the human body. They have less side effects and better effectiveness. The engineered drugs are all the more expensive, having limited edge of wellbeing and more results when contrasted with natural CNS stimulants which are having wide edge of wellbeing, less expensive what's more, having mild side effects than synthetic medications, so more research is going on natural medications in CNS disorders. However, information regarding the herbal medication being classified in such a way might be helpful in drug formulations, drug substitution and also in systematizing our knowledge in this regard. This review can be helpful in creating mass awareness regarding the importance and need in conserving and preserving such plant species and also in the promotion of herbal medicinal knowledge within and outside the region and also enrichment of the gene bank for such economically important species before they are lost forever.

\section{CONFLICTS OF INTEREST}

The authors of the article have no conflicts of interest.

\section{REFERENCES}

1. https://teachmephysiology.com/nervoussystem/components/central-nervous-system/ Georgie Banks (2018); Central Nervous System.[Cited 2020 November 21, 5:17pm]

2.Y Ravi , KV Suryakant, N Sudharani , Nagaraj Gokavi, MK Sunilkumar, KR Akshay ; Importance of medicinal plants in the treatment of central nervous system disorders - A review; December 14, 2015[Cited 2020 November 21, 5:23pm]

3. Krames, Peckham, Rezai (eds), Neuro modulation v.1-2, p. 978. (2009) [Cited 2020 November 21, 5:34pm]
4. Pardridge W. Journal of Cerebral Blood Flow \& Metabolism 32, 1959-1972. (November 2012) [Cited 2020 November 22, 4:21pm]

5. National Institute of Neurological Disorders and Stroke (NINDS). AAV2-GDNF for Advanced Parkinson's Disease In ClinicalTrials.gov [Internet], Bethesda (MD): National Library of Medicine (US). 2000- [cited 2013 Sept. 23]. Available from: http://clinicaltrials.gov/ct2/show/NCT01621581 NLM Identifier: NCT01621581 [Cited 2020 November 24, $2: 18 \mathrm{pm}]$

6. (DOI: 10.1002/ptr.1970; Kumar V ; Potential Medicinal Plants for CNS Disorders: An Overview; published on 14 August 2006 in Wiley InterScience; Copyright (C) 2006 John Wiley \& Sons, Ltd. Phytother. Res. 20, 1023-1035 (2006) [Cited 2020 November 24, 2:34pm]

7. Hynniewta, SR, Kumar, Y; "Herbal remedies among the Khasi traditional healers and village folks in Meghalaya"; CSIR; Oct-2008; available from: http://hdl.handle.net/123456789/2383 [ Cited 2020 November 24, 3:09pm]

8. Sharma HK, Chhangte L, Dolui AK; 'Traditional medicinal plants in Mizoram, India'; February 19, 2001; available from:https://doi.org/10.1016/S0367-326X(00)002781[ Cited 2020 November 24, 3:37pm]

9. Dolui AK, Sharma HK, Marein TB, TcLalhriatpuii; 'Folk herbal remedies from Meghalaya'; Indian Journal of Traditional Knowledge Vol. 3(4), October 2004, pp. 358364; September 10,2003. [ Cited 2020 November 27, 7:04am]

10. Amalraj A et al. J Tradit ,Biological activities of curcuminoids, other biomolecules from turmeric and their derivatives - A review Complement Med. 2016. [[ Cited 2020 November 28, 8:07pm]

11. Usharani P, et al. Effect of NCB-02, atorvastatin and placebo on endothelial function, oxidative stress and inflammatory markers in patients with type 2 diabetes mellitus: a randomized, parallel-group, placebocontrolled, 8-week study. Drugs R D. (2008)[ Cited 2020 November 28, 8:47pm]

12. Venkataranganna MV, et al. NCB-02 (standardized Curcumin preparation) protects dinitrochlorobenzeneinduced colitis through down-regulation of NFkappa-B and iNOS. World J Gastroenterol. (2007)[Cited 2020 November 29, 2:34pm]

13.Jurenka JS, Anti-inflammatory properties of curcumin, a major constituent of Curcuma longa: a review of preclinical and clinical research. Altern Med Rev. (2009) [ Cited 2020 November 31, 7:02pm]

14. Se-Whan Lee et al. Int J Cardiol.; Transient complete atrioventricular block associated with curcumin intake; 2011 [Cited 2020 November 31, 7:15pm]

15. Roodenrys, S., Booth, D., Bulzomi, S., Phipps, A., Micallef, C., and Smoker, J. Chronic effects of Brahmi (Bacopa monnieri) on human memory. Neuropsychopharmacology[ Cited 2020 November 31, $7: 27 \mathrm{pm}]$

16.Singh, R. H. and Singh, L. Studies on the Anti-Anxiety Effect of the Medhya Rasayana Drug, Brahmi (Bacopa monniera (L.) Wettst.) - Part I. Journal of Research in Ayurveda and Siddha 1980;1(1):133-148. [Cited 2020 December 2, 7:08am ] 
17. Benson S, Downey LA, Stough C, et al. An acute, doubleblind, placebo-controlled cross-over study of $320 \mathrm{mg}$ and $640 \mathrm{mg}$ doses of Bacopa monnieri (CDRI 08) on multitasking stress reactivity and mood. Phytother Res 2014; 28(4):551-9.[ [Cited 2020 December 2, 7:23am ]

18. Singh M, Murthy V, Ramassamy C. Modulation of hydrogen peroxide and acrolein-induced oxidative stress, mitochondrial dysfunctions and redox regulated pathways by the Bacopa monniera extract: potential implication in Alzheimer's disease. J AlzheimersDis 2010; 21:229-47. [Cited 2020 December 2, 7:33am ]

19. Uabundit N, Wattanathorn J, Mucimapura S, Ingkaninan K. Cognitive enhancement and neuroprotective effects of Bacopa monnieri in Alzheimer's disease model. J Ethnopharmacol 2010; 127:26-31. [Cited 2020 December 4, 10:11am]

20. Wei Lui, TongtongGe, [...], and Bingjin Li; "the effect of herbal medicine on epilepsy"

https://www.ncbi.nlm.nih.gov/pmc/articles/PMC56465 6/\#!po=45.1389 [ Cited 2020 January 6, 10:43am ]

21. Brinkhaus, B., Lindner, M., Schuppan, D. \& Hahn, E. G. Chemical, pharmacological and clinical profile of the East Asian medical plant Centella asiatica. Phytomedicine 2000; 7:427-448.[ Cited 2020 January 6, 10:59am ]

22. World Health Organization. (World Health Organization, Geneva, Switzerland, 1999).[ Cited 2020 January 6, 11:15am ]

23. Vaidya AD. \&Devasagayam, TP. Current status of herbal drugs in India: an overview. J ClinBiochemNutr 2007; 41:1-11, doi:10.3164/jcbn.2007001 [Cited 2020 January 7, 10:43am]

24.https://www.sciencedirect.com/topics/agricultural-andbiological-sciences/matricaria-

chamomilla\#: :text=Chamomile\%20(Matricaria\%20Rec utita

$\% 2 \mathrm{C} \% 20$ also,infection $\% 2 \mathrm{C} \% 20$ wounds $\% 2 \mathrm{C} \% 20$ and $\% 2$ 0burns. [ Cited 2020 January 7, 1:17pm ]

25. Maclennan KM et al, ProgNeurobiol; "The CNS effects of Ginkgo biloba extracts and ginkgolide B"; 2002 June [ Cited 2020 January 7, 1:22pm ]

26.

https://www.sciencedirect.com/science/article/pii/S13 19562X19302591\#: :text=Camellia\%20sinensis\%20L. $\% 20$ has $\% 20$ long,and $\% 20$ leaf $\% 20$ extracts $\% 20$ on $\% 20 \mathrm{mi}$ ce. [Cited 2020 January 11, 8:06am ]

27. Maharjan H. Radha and Nampoothiri P. Laxmipriya; Evaluation of biological properties and clinical effectiveness of Aloe vera: A systematic review. https://www.ncbi.nlm.nih.gov/pmc/articles/PMC44881 01/ [Cited 2020 January12, 10:44pm ]

28. Bernardi MM, Kirsten TB. Antidepressant like effects of an apolar extract and how enriched with nepetacataria in mice.2010;3(2): 251-25[ Cited 2020 January 12, $11: 09 \mathrm{pm}]$

29. Satish s: Studies on Therapeutic Potential of Essential Oils of NepetaCataria in Treatment of Alzheimer's Disease. Asian Journal of Biomedical and Pharmaceutical Sciences; 2013; 3(18):42-48. [Cited 2020 January 12, $11: 24 \mathrm{pm}]$

30. Ketakee D. Celastruspaniculatus: Traditional uses and Ethnobotanical study; https://www.researchgate.net/publication/281626232_ Celastrus_paniculatus_Traditional_uses_and_Ethnobotani cal_study; September 2015 [ Cited 2020 January 12, $11: 44 \mathrm{pm}]$

31.Paithankar VV, Belsare SL, Charde RM, Vyas JV. AcorusCalamus: an overview, Int J Biomed Res 2011; 2(10): 518-29. [ Cited 2020 February 5, 5:23pm ]

32. Pattanaik J, Kumar Y, Khatri RS. Acoruscalamus Linn: a herbal tonic for central nervous system. J Sci Innovative Res 2013;2(5):950-4 [ Cited 2020 February 5, 5:34pm ]

33. Kataria D, Kumar C, Nerkar N, Gadiya RV, Abhyankar MM. Detail profile of Crocus sativus. Int J Pharma Bio Sci 2011;2(1):530-40. [ Cited 2020 February 5, 5:45pm ]

34. Jaggi RK, Madaan R, Singh B. Anticonvulsant potential of holy basil, Ocimum sanctum Linn and its cultures. Ind J Exp Biol 2003; 41:1329-33 [ Cited 2020 February 5, $5: 49 \mathrm{pm}]$

35. Emamghoreishi M, Heidari-Hamedani G. SedativeHypnotic activity of extracts and essential oil of coriander seeds; Iran J Med Sci 2006; 31(1):22-7 [ Cited 2020 February 5, 6:02pm ]

36. Hosseinzadeh H, Madanifard M. Anticonvulsant effect of Coriander sativum L. seed extracts in mice. Iran J Pharm 2005;3:1-4 [ Cited 2020 February 6, 7:08pm ]

37.Uddin Q, Samiulla L, Singh VK, Jamil SS. Phytochemical and pharmacological profile of Withania somnifera Dunal: a review. J Appl Pharm Sci 2012; 02(01):170-5 [ Cited 2020 February 6, 7:35pm ]

38. https://www.sciencedirect.com/topics/biochemistrygenetics-and-molecular-biology/emblica-officinalis [ Cited 2020 February 7, 3;45pm ]

39. R. JasminSajini *, S. Prema and K. Chitra; PHYTOCONSTITUENTS, PHARMACOLOGICAL ACTIVITIES OF MARSILEA MINUTA L. (MARSILEACEAE) - AN OVERVIEW https://ijpsr.com/bftarticle/phytoconstituents-pharmacological-activities-ofmarsilea-minuta-l -marsileaceae-anoverview/?view=fulltext [ Cited 2020 February 8, $4 ; 30 \mathrm{pm}]$

40. Punit P, Shahl, P M D'Mello*; A review of medicinal uses and pharmacological effects of Menthapiperita; Natural Product Radiance Vol 3(4) July-August 2004 [ Cited 2020 March 5, 5:23pm ]

41. Peng Q, Buz-Zard AR and Lau BH: Neuroprotective effect of garlic compounds in amyloid-beta peptide-induced apoptosis in-vitro. Med SciMonit 2002; 8(8): BR 328-37.[ Cited 2020 March 5, 8:06pm ]

42. Chauhan NB: Effect of aged garlic extract on APP processing and tau phosphorylation in Alzheimer's transgenic model Tg 2576. J of Ethnopharmacology 2006; 108(3):385-94.[ [ ited 2020 March 5, 9:03pm ]

43.Nishiyama N, Moriguchi T, Morihera N and Saito H: Ameliorative effect of Sallylcysteine, a major thioallyl constituents in aged garlic extract, on learning deficits in senescence-accelerate mice. J of Nutrition 2001; 131: 1093S-1095S.[ Cited 2020 March 5, 9:15pm ]

44. Bongiorno PB, Fratellone PM and LoGiudice P: Potential health benefits of Garlic (Allium sativum): a narrative review. Journal of Complementary and Integrative Medicine 2008; [Cited 2020 April 27, 3:07pm ] 
45. Barman S, Raha A, Majumder M,Bagchi A; Activity of ginseng on central nervous system; https://www.researchgate.net/publication/333394982 Activity_of_ginseng_on_central_nervous_system \#: :text=Panax\%20ginseng\%20is\%20used $\% 20$ in,are $\%$ 20mainly\%20triterpenoid\%20dammarane\%20derivativ es; May 2019 [ Cited 2020 April 27, 4:33pm ]

46. Muhammad AH, Khan A, Farooq HU, Perveen S; Traditional Uses, Phytochemistry, and Pharmacology of Olea europaea (Olive); https://doi.org/10.1155/2015/541591; volume 2015; published 23 Feb 2015[ Cited 2020 April 28th, 9:05am ]

47. Xin-zhi Sun, Ying Liao, [...], and Li-meiGuo, M.D.; Neuroprotective effects of ganodermalucidum polysaccharides against oxidative stress-induced neuronal apoptosis . https://www.ncbi.nlm.nih.gov/pmc/articles/PMC55148 71/ [Cited 2020 April 28th, 9:13am ]

48. Dhawan K, Kumar S, Sharma A; Evaluation of Central Nervous System Effects of Passifloraincarnata in Experimental Animals; 29 Sep 2008: https://doi.org/10.1076/phbi.41.2.87.14241; [ Cited 2020 April 28th, 9:34am ]

49.Mikawlrawng K, Prakash G; Anti-paralytic medicinal plants - Review; https://www.sciencedirect .com/science/journal/22254110 ; Volume 8, Issue 1, January 2018, Pages 4-10 [Cited 2020 April 28th, 9:44am ]

50. Magaji RA, Saleh MIA, Magaji MG, I. Buhari. Preliminary Central Nervous System Effects of the Aqueous Seed Extract of Mucuna pruriens in Mice; DOI: 10.3923/crn.2014.6.9; Year: 2014; 4(1):6-9 [Cited 2020 April 28th, 10:03am ]

51. Sharma A, Goyal R ,Sharma L. Potential biological efficacy of Pinus plant species against oxidative, inflammatory and microbial disorders; Published: 28 January 2016.[ Cited 2020 April 28th, 10:16am ]

52.Mojaverrostami S, Bojnordi MN, [...], Hamidabadi HG; A Review of Herbal Therapy in Multiple Sclerosis; 2018 nov 19, Doi- 10.15171/apb.2018.066[ Cited 2020 April 28th, 10:27am ] 